\title{
Iterative Multi-draft Model in Expository Problem-solution Composition
}

\author{
Arfan Fahmi \\ Department of Social Sciences and Humanities \\ Institut Teknologi Sepuluh Nopember (ITS) Indonesia \\ ITS Campus Keputih Sukolilo Surabaya 6011 \\ Indonesia \\ arfan@mku.its.ac.id
}

\begin{abstract}
University writing teachers in EFL writing programs are likely familiar with multi-draft composing. The researcher argues that multi-draft composing as it is currently used within second language writing programs can be overwhelming for EFL student. In this study, He introduces the iterative multi-draft model, a revised and more manageable version of the traditional multi-draft model, in EFL context. In a traditional multi-draft model, students generally complete a composition as part of a stand-alone, fixed-form writing unit and then move on to an entirely new and often unrelated genre. The students in this model learn a writing process and practice it in three unique and apparently unrelated compositions. Students in the iterative model learn a process and repeat it three times in compositions that clearly build on one another. He applies this model on EAP students to help master essential writing skills in expository composition. A study of 108 compositions written by 36 students in three meetings within two weeks in EAP course at Institut Teknologi Sepuluh Nopember ITS Indonesia rated by 2 raters demonstrates that the new model can be effective in improving students' composition. The iterative model through a series of repeated measure univariate ANOVA produces a statistical effect on writing scores in three writing sub skills (content, F(5.34) at Sig 0.01, organization, F(15. 59) at Sig 0.00, grammar, F(16.91) at Sig 0.00, and overall F(20.31) at Sig 0.00). Additionally, the students' perceptions of the model on 5 Likertscale questionnaire further indicate that they have positive perspectives on their experience in applying this model (Mean = 4.42). This result supports the need for EFL writing instructors to continue to develop materials that teach the skills of process writing, genre recognition, and reader awareness. It also suggests to the prospective writer to read and understand at least three models before starting to write.
\end{abstract}

Key words: Expository writing; Writing development; English for academic purposes

\section{Introduction}

There is an ongoing need to create educational settings that address the cognitive, social, and emotional needs of students. The need for developmental writing instruction is widespread and affects most higher education institutions, Furthermore, there is a need for systematic research that provides reliable results about interventions in order to inform and guide educators' practice. Particularly, attention needs to be paid to the development of higher order reading, writing, and critical thinking skills required to tackle today's increasing literacy demands.
One area required to attentively focus on is writing. A number of approaches have been introduced to raise the quality of English as a Foreign Language (EFL) students' compositions. Product-based approach, process-based approach, and genrebased approach are among those alone or in combination to be deliberately applied to reach the goal. Inspired by the process-based approach, which focuses on the four stages of writing: planning, drafting, revising, and editing (Campbell, 1998). One form of process-based writing is traditional multi-draft composing. It requires students to write successively improved 
drafts of a single composition in a particular genre between periods of feedback from peers, tutors, and/or teachers. It forces and mechanizes the act of revision associated with good writing Eckstein, Chariton, and McCollum (2011).

Several reasons why a traditional, compositionbased multi-draft model can be ill suited for writers in developing academic literacy and writing skills. Eckstein, Chariton, and McCollum (2011) exemplify that ESL students must develop composition skills through the language of instruction, which may be a thick filter for students with proficiency deficiencies. These writers must also navigate the linguistic, sociocultural, and ideological landscape to produce a culturally appropriate genre-specific composition. In addition, when ESL writers are required to write multi-draft compare-contrast, opinion, and research compositions all in the same semester, they must tend to the rhetorical or generic novelty of each composition. This is particularly amplified when ESL writers are asked to intuitively understand the culture and power positions of a prescribed audience in order to shape readersensitive prose and grammatically common expectation from composition practitioners. For less experienced or less proficient ESL writers, this combination of skills and requirements can completely shut down the writing process in a second language even when the assignment seems simple.

There should be an attempt to eliminate the barriers in applying this model. Responding to that unfit condition, Eckstein, Chariton, and McCollum
(2011) introduced iterative multi draft model. It is a strategy emphasizing on the importance of repeating a procedure in order to improve the quality of the composition. In this model, students begin an argument in the first multi-draft assignment, expand it in the next assignment (the second iteration), and resolve it in a final assignment (the third iteration). This is different from a traditional multi-draft model where students generally complete a composition as part of a stand-alone, fixed-form writing unit and then move on to an entirely new and often unrelated genre in the next assignment. Thus students in the traditional model learn a writing process and practice it in three unique and ostensibly unrelated compositions. Students in the iterative model learn a process and repeat it three times in compositions that clearly build on one another and better separate genre components

The procedure in the iterative model begins with writing assignment and repeats it several times. In Eckstein, Chariton, and McCollum (2011) previous research, Twenty six students should do in a writing class. They have to select topics for their first multi-draft assignment. Students compose drafts of their expository argumentative composition. The drafts are submitted to the teacher to be rated and given score as well as formative feedback. The students then revise the drafts and give back to the teacher and their friend as a source material for the next assignment. For their second composition, students are asked to choose a topic from among those already addressed by their peers. This exchange of topics is accompanied by an exchange of actual 
compositions so each student may begin expanding one another's ideas. Students also obtain important background information on the new topic in terms of critical thought from the first author. Like in the first composition, the drafts are submitted to the teacher to be rated and given score as well as given formative feedback. The students revise the drafts and give back to the teacher and their friends as source material for the next assignment. The same procedure takes place when moving to the third composition. The only difference is that in the third composition, the writer has two compositions from previous student peers. The drafts in third composition are the last composition to be rated and given score.

Implemented in one semester period, the iterative model gains promising students' writing improvement. Eckstein, Chariton, and McCollum (2011) report that the result of repeated measure on students' composition using univariate ANOVA showed a significant effect for content, $F(2,39)$ 1/4 7.77, $p<.01$, organization, $F(2$, 39) $1 / 46.16, p<.01$, and grammar, $F(2,39) 1 / 411.68$, $\mathrm{p}<.001$. However, the analysis did not show a significant effect for word choice, $\mathrm{F}(2,39) 1 / 40.58$, $p>.05$ or references, $F(2,39) 1 / 42.68, p>.05$. This suggests that participants in the study improved in at least some of their writing skills from the beginning of the semester to the end.

The present study differs from the previous study in several ways. Firstly, it focuses on the ability to write expository composition rather than academic argument writing. This genre is generally understood to constitute the majority of college- based reading.. There are several types of expository text structures that serve to organize the material, and the most common are often identified as time sequence, description, explanation/process, comparison-contrast, problem-solution, and cause and effect (Gunning,2010). To be more specific, this study focuses on the ability to compose expository problem-solution composition. Problem-solution writing is defined as the author's ability to identify and formulate the problems, seek possible solutions and come up with reasonable solution. This skill is particularly important in today's society where the increased use of online technology heightens the need to understand expository writing because in an online environment the way to create a visual representation is essential to the reader's understanding. Therefore, writers must use appropriate descriptive language to get their message across (Mongillo and Wilder:2012).

Secondly, the context of the study is in English as a foreign language (EFL) environment in which the students do not use English for daily communication. Unlike Eckstein, Chariton, and McCollum (2011) study, which is implemented in ESL context, EFL environment provides less spoken and written language exposure to the students. In this context, the role of model is essential to provide a real picture of the composition intended to produce.

Thirdly, the effect of model exposure is the main concern. In this present study, in three successive meeting within two weeks, the students have to 
write three compositions in three different topics. Therefore, unlike the previous study, Eckstein, Chariton, and McCollum (2011), which includes formative feedback from the teacher, this study does not include any kind of feedback intended to improve the students' compositions. In short, exposed to the model texts only, the students produce three compositions in the same genre, problem-solution composition, with three different topics successively.

In sum, this study is firstly designed to determine if the implementation of the iterative model resulted in better overall students' writing scores in three sub-skills of writing (organization, content, grammar). Secondly, it investigates the students' perceptions of this model application.

This study is firstly designed to determine if the implementation of the iterative model resulted in better overall students' writing scores, and in three sub-skills of writing (organization, content, grammar). Secondly, it investigates the students' perceptions of this model application.

\section{Method}

The researcher hypothesizes that the students implementing the iterative model would significantly improve their overall writing scores in all three sub-skills of writing (organization, content, and grammar) in a repeated measure of expository problem-solution writing.
The participants derives from one randomly selected class out of five English classes at one engineering faculty in a recognized institute of technology in Indonesia. The class consists of 41 students. However, only thirty six students fully participate in the study, two students partially join the implementation, and three are dropped due to their confusion of the process engaged reflected in the questionnaire responses. The thirty six students are randomly assigned to produce three compositions in three meeting with three different topics within two weeks in iterative multi draft model implementation.

The implementation procedure of this model is elaborated as follows; in the first meeting, the students are given a short description of problemsolution composition and exposed to one model from the teacher and are asked to read and understand carefully, then they are randomly assigned to write one of three topics to produce the first composition. In the second meeting, despite one model from the teacher, the students are given one model from their peer previously written composition in the same topic, which is different from the first composition, and asked to read and understand carefully before writing the second composition. At last, in the third meeting, despite one model from the teacher, they are given two models from their peer previously written compositions in the same topic, which is different from the first and the second composition, and asked to read and understand carefully before writing the third composition. The table below illustrates the procedure. 
Table 1: The iterative multi-drafts model

\begin{tabular}{|c|c|c|c|}
\hline & RAHMAT & NOVIANA & EVA \\
\hline \multirow[t]{3}{*}{ Meeting 1} & TOPIC A & TOPIC B & TOPIC C \\
\hline & TEACHER MODEL & TEACHER MODEL & TEACHER MODEL - \\
\hline & $-\rightarrow$ Composition 1 & $-\rightarrow$ Composition 1 & $\rightarrow$ Composition 1 \\
\hline \multirow[t]{4}{*}{ Meeting 2} & TOPIC C & TOPIC A & TOPIC B \\
\hline & TEACHER MODEL & TEACHER MODEL + RAHMAT & TEACHER MODEL + NOVIANA \\
\hline & COMPOSITION & COMPOSITION & COMPOSITION $-\rightarrow$ Composition 2 \\
\hline & $-\rightarrow$ Composition 2 & $-\rightarrow$ Composition 2 & \\
\hline \multirow[t]{4}{*}{ Meeting 3} & TOPIC B & TOPIC C & TOPIC A \\
\hline & TEACHER MODEL +NOVIANA & TEACHER MODEL +EVA & TEACHER MODEL +RAHMAT \\
\hline & +EVA COMPOSITION & +RAHMAT COMPOSITION & +NOVIANA COMPOSITION \\
\hline & $-\rightarrow$ Composition 3 & $-\rightarrow$ Composition 3 & $-\rightarrow$ Composition 3 \\
\hline
\end{tabular}

One hundred and eight compositions from 36 students are collected and analyzed. Thus, in every stage, there are 36 drafts as the source of data. A writing rubric is used to evaluate the compositions. Two raters are involved in the evaluation. To ensure high inter-rater reliability, scores varying by a single point are averaged, and scores varying by more than one point are arbitrated by a third rater. Having completed the third composition, students respond to a given 5 Likert-scale questionnaire investigating their perceptions on this model application.

\section{RESULTS}

To investigate the implementation of the iterative model repeated measure univariate ANOVA is run on each subskill of writing score (content, organization, and grammar) as well as overall writing score (see Table 2). The results showed a significant effect for content, $\mathrm{F}(5,34), \mathrm{p}<.01$, organization, $\mathrm{F}(15,59), \mathrm{p}<.01$, and grammar, $\mathrm{F}(16,91), \mathrm{p}<.01$ as well as overall $\mathrm{F}(20,31), \mathrm{p}<$ .01 This suggests that participants in the study improved at all subskills of their writing within 3 class meeting in two weeks. Due to the low number of participants, it makes difficult to generalize to other situations.

Table 2. ANOVA for data analysis in iterative model

\begin{tabular}{llllll}
\hline SUBSKILL & & $\mathrm{M}$ & $\mathrm{SD}$ & F-test & $\mathrm{Sig}$ \\
\hline CONTENT & COMP 1 & 3.39 & 0.80 & 5.34 & 0.006 \\
& COMP 2 & 3.67 & 0.63 & & \\
& COMP 3 & 3.92 & 0.60 & & \\
ORGANIZATION & COMP 1 & 3.31 & 0.47 & 15.59 & 0.00 \\
& COMP 2 & 3.64 & 0.49 & & \\
GRAMMAR & COMP 3 & 3.92 & 0.44 & & \\
& COMP 1 & 3.39 & 0.60 & 16.91 & 0.00 \\
& COMP 2 & 3.67 & 0.48 & & \\
OVERALL & COMP 3 & 4.08 & 0.44 & & \\
& COMP 1 & 10.08 & 1.50 & 20.31 & 0.00
\end{tabular}


$\begin{array}{lll}\text { COMP } 2 & 10.97 & 1.18\end{array}$

$\begin{array}{lll}\text { COMP } 3 & 11.92 & 0.91\end{array}$

\section{Discussion}

The students' responses on 5 Likert-scale questionnaire indicates that they have positive perceptions on this model application (see Table $3)$.

Table 3: Students' perception on iterative multi-draft model application

\begin{tabular}{|c|c|c|c|}
\hline $\mathrm{NO}$ & FEEDBACK ITEM & $\mathrm{M}$ & SD \\
\hline 1 & $\begin{array}{l}\text { The description of expository writing is } \\
\text { clear }\end{array}$ & 4.53 & 0.755 \\
\hline 2 & $\begin{array}{l}\text { The description of iterative multi-draft } \\
\text { model is clear }\end{array}$ & 4.58 & 0.642 \\
\hline 3 & I like this model & 4.47 & 0.547 \\
\hline 4 & This model can improve my writing & 4.14 & 0.528 \\
\hline 5 & $\begin{array}{l}\text { I feel comfortable participating in this } \\
\text { model }\end{array}$ & 4.36 & 0.485 \\
\hline 6 & $\begin{array}{l}\text { I like to share my composition with my } \\
\text { friend in meeting } 2 \text { and } 3\end{array}$ & 4.41 & 0.672 \\
\hline 7 & $\begin{array}{l}\text { I like to have my friend's composition } \\
\text { in meeting } 2 \text { and } 3\end{array}$ & 4.31 & 0.58 \\
\hline 8 & $\begin{array}{l}\text { Reading my friend's composition in } \\
\text { meeting } 2 \text { and } 3 \text { help me write better }\end{array}$ & 4.42 & 0.642 \\
\hline 9 & $\begin{array}{l}\text { I think that my writing is improved in } \\
\text { meeting } 2 \text { and } 3\end{array}$ & 4.50 & 0.752 \\
\hline 10 & $\begin{array}{l}\text { Having participated in this model, my } \\
\text { confidence in writing increases }\end{array}$ & 4.44 & 0.887 \\
\hline
\end{tabular}

In relation to one word response reflecting the students' feeling on their experience in applying iterative multi-draft model writing, most of their words imply positive attitude. The word "good" and "relaxed" are the most frequently stated word with $11 \%$ appearance each. In the second place the word "happy", "interesting", "tiring", "strange", "OK", "common", "enjoyable" and "more" get $8.3 \%$. The word "surprised" gain 5.5\%.The least frequently appeared words are "seldom" and "excellent" with $2.8 \%$

This study investigates the application of the proposed iterative model by 1) investigating student writing scores in an iterative setting over three meetings in two weeks and 2) investigating the student perception of the application of this model. The researcher anticipates that student writing in the iterative model would improve over three meetings in three areas: content, organization, and grammar. He also anticipates that the students' perception of the application is positive.

Content and organization scores improved over the meetings of two weeks using the iterative model. This is likely because the iterative model facilitates synthesis of information. For example, students must initially collect, synthesize, and order information when writing their first compositions. But when students begin their second composition, much of the synthesis has already been done by fellow classmates. This allows students to comprehend the content much more effectively and discuss it with their informed peers. In much the same way that content is managed and re-managed by subsequent writers, organization is also revisited, revised, and improved from writer to writer. For instance, if a second student encounters an unclear sentence in a previous student's composition, the second student is likely to notice the problem and then rewrite or reorganize in the new essay. Yang and Zhang (2010) found that formulation of model texts resulted in better 
composition in EFL context. In Their research, they deliberately formulate the model texts given to the students on some targeted points expecting that the students learn by reading and understanding the models. The same process is repeated for the final composition. The continual collaboration, revision, and reworking of ideas lends itself to the particular needs of EFL students and allows them to improve their content and organization scores. However, there is no inherent reason for grammar to improve over the application period of three iterative essays because in paraphrasing and revising others' work, novel grammatical structures are necessary, meaning new grammar errors could be introduced. It is possible that grammar scores improved as students negotiated meaning and wordage with classmates, but it is more likely that intervening variables contributed to the gains of grammar scores. However, it is important to recognize that the iterative model facilitated rather than impeded grammar development in this study.

The improvements made by these students are likely because of the key differences that distinguish the iterative model from a traditional model. These include, for example, a more integrated genre approach, an increased focus on explicitly teaching composition skills, and more authentic peer exchanges. In fact, this extemporaneous and meaning-driven peer exchange is perhaps the most important component of the iterative model because it promotes a more holistic communication environment. Where Student A and Student B have different language backgrounds, the peer exchange process is even more effective for building and practicing communicative language skills. If two or more students are writing on the same topic at the same time, they can form a team to research and revise their compositions together. This is a common feature of collaborative writing in the "real world" for which their education should prepare them (Sasaki, 2000). All of this creates an environment where students view each other as audience members and collegial writers. Having a tangible, immediately responsive audience can help students develop more authentic audience awareness and thus demonstrate a clearer voice in their writing (Ramanathan \& Kaplan, 1996).

Another factor contributed to the improvement is model exposure. As the students go along with their compositions, they expose to more and more model; one model in the first composition, two models in the second and three models in the third. This allows them to familiarize with the genre and in turn they can produce better composition. Referring to this factor, Wette (2014) reveals that repeated use of a number of instructional strategies that can be termed "modeling" enhances text production focusing on the processes involved in creating a particular text by activating and formulating cognitive processes while producing composition. In addition, in analyzing how students develop genre knowledge, Tardy's (2006) review of sixty empirical studies suggests that that L1 and L2 learners in classroom and nonclassroom contexts share the following experiences in learning new genres: Learners are 
influenced by their prior experiences and practice with genres, they have difficulty in transferring genre knowledge across settings and contexts, and they make use of implicit exposure to genre and more explicit textual resources such as written models to learn new genres.

Yasuda (2011) Enhanced awareness of the external context, involving the needs of the audience and the purpose of writing, enabled writers to develop a range of linguistic choices to make when performing a certain social action. The study concludes that writing development is not due to a decontextualized mechanical process of learning a new lexical item but an expansion in linguistic resources to make meaning in a specific social context.

Reader awareness likely contributes to the improvement. When the students engage in the process of writing, they know that their composition is going to be read by their friends. This makes them aware of the importance of the composition. Therefore they write carefully at their best to produce good composition. Establishing reader awareness in novice writer suggests positive input to the improvement of his or her writing. Thompson (2001) resumes that the perspective of written texts as embodying interaction between writer and reader is initially introduced and trained to novice writer of academic texts.

The writer development is complex in nature in that the contributing factors vary. Wardle and Roozen (2012) introduced an ecological perspective of literate development that situates students' growth as writers across multiple engagements with writing, including those outside of school.

Following the application of this model, he solicits student perceptions on the iterative model. Thirtysix participants provided feedback on their class experience by responding to a ten-statement survey on 5 Likert-scale (see Table 5).The results show that all statements are responded positively.

Concerning the students' understanding of the model, statement 1 and 2, the description of expository writing is clear and the description of iterative multi-draft model is clear, are responded positively by the students with M 4,53, SD 0,755 and $\mathrm{M} 4,58, \mathrm{SD} 0,642$. It indicates that students possess good understanding of the writing task that they are about to participate in. This is important to ensure that the participants writing process is on the right track.

In relation to the feeling when the students engage in the model, statement 3, 4, and 5, I like this model, this model can improve my writing, and I feel comfortable participating in this model, have also positive responses from the students M 4,47 SD 0,547, M4,14 SD 0,528, and M 4,36 SD . It shows that the students feeling when they engage in this model. The students' happiness, comfort, and belief of the improvement create constructive learning atmosphere. 
In respect to open-mind and reader awareness concept, statement 6 and 7, I like to share my composition with my friend in meeting 2 and 3 and I like to have my friend's composition in meeting 2 and 3, are also responded positively by the students with M 4.41 SD 0.672 and M 4.31 SD 0.58 . It indicates that the students are willingly share and receive the composition. They are open mind to let their friends read their composition. This can also trigger their attentions when they are writing as they possess a kind of feeling that they have to produce good composition since their friends later will read the composition.

Belief in improvement and confidence are elicited through statement 8,9 , and 10 , I think that my writing is improved in meeting 2 and 3 and having participated in this model, my confidence in writing increases. The two statements gain positive responses from the students with M 4.50 SD 0.752 and M 4.44 SD 0.887. It means that the students believe that their ability and confidence in writing increase after completing the three-meeting activity in two weeks.

In this study, peer influence is a variable that the researcher is unable to fully control. This variable is likely to have an effect on the results. Further research with tighter variable control is required to establish the strength of that claim that reading and understanding at least 3 model texts in iterative multi draft model can improve writing quality. However initial evidence, if provided, indicates that the iterative model does produce some better writing.

\section{Conclusion}

The present study shows that an iterative model of multi-draft writing geared toward the needs of EFL writers results in improved writing in three areas: organization, content, and grammar over three meetings in two weeks. A single model that can positively implicate both writing teacher and writing student or anyone who wants to have better writing. It can substantially reduce the workload of the teacher and still provide the learner with valuable experiences for developing EFL writing skills by exposing them with at least three composition model and asking them to write three times. For writing students and prospective writers, this model can provide evidence that before writing anything it is well suggested that one has to read carefully at least three models to get better understanding of the content, organization and grammar used in a particular genre.

This result supports the need for EFL writing instructors to continue to develop materials that teach the skills of process writing, genre recognition, and reader awareness. Significantly, the iterative model also provides a type of multidraft composing that clearly distinguishes itself from its composition counterpart. This increases the philosophical uniqueness of EFL writing instruction and helps unmask the superficial allegiance of the composition and EFL writing field. 


\section{Acknowledgement}

The researcher would like to thank Prof. Ali Saukah, M.A, Ph.D for his valuable strategy in introducing what so called publication-based research and his insightful comments and suggestions throughout the development of this work in his course, Writing for Publication, in ELT doctorate program at State University of Malang (UM) Indonesia. He also thanks his colleague, Umi Trisyanti, for her willingness to provide her classroom context for this research. .To all 36 freshmen of Dipl 3 Mechanical Engineering students in Class B 2013 Institut tekonologi Sepuluh Nopember Indonesia participating in this work, he expresses his sincere gratitude.

\section{References}

Campbell, C. (1998). Teaching secondlanguage writing: Interacting with text. Newbury: Heinle \& Heinle

Eckstein Grant, Chariton, Jessica and McCollum, Robb Mark. (2011) Multidraft Composing: An Iterative Model for Academic Argument Writing Journal of English for Academic Purposes Vol 10 Issue 3 (September 2011)

Gunning, T. G. (2010). Assessing and

Correcting Reading and Writing Difficulties (4th ed.). Boston, MA: Allyn \& Bacon.

Mongillo, Geraldine and Wilder, Hilary (2012)
An Examination of At-risk College Freshmen's Expository Literacy Skills Using Interactive Online Writing Activities in Journal of College Reading and Learning. 42.2 (Spring 2012)

Plakans, L., \& Gebril, A. (2012). A close investigation into source use in integrated second language writing tasks. Journal Assessing Writing, Vol 17 Issue 1 (January 2012)

Ramanathan, V., \& Kaplan, R. B. (1996). Audience and voice in current L1 composition texts: some implications for ESL student writers. Journal of Second Language Writing, Vol 5 Issue 1 (1996)

Sasaki, Miyuki. (2000). Toward an empirical Model of EFL Writing Processes: An Exploratory Study. Journal of Second Language Writing Vol 9.Issue3 (2000)

Tardy, C. M. (2006). Researching first and second language genre learning: A comparative review and a look ahead. Journal of Second Language Writing, Vol 15 Issue 1 (2006)

Thompson, Geoff. (2001) Interaction in academic writing: learning to argue with the reader. Applied Linguistics Vol 22 Issue 1 (2001)

Wardle, Elizabeth and Roozen, Kevin (2012) Addressing the complexity of writing development: Toward an ecological model of assessment. Assessing Writing Vol 17 Issue 1 (2012)

Wette, Rosenary. (2014) Teachers' practices in EAP writing instruction: Use of models and modeling. Systen Vol 42 February 2014

Yang, L and Zhang, L (2010). Exploring the role of reformulations and a model text in EFL students' Writing Performance. Language Teaching Research Vol 14 Issue 4 (2010) 
Yasuda, Sachiko. (2011) Genre-based tasks in foreign language writing: Developing writers' genre awareness, linguistic knowledge, and writing competence. Journal of Second Language Writing Vol 20 Issue 2

\section{APPENDIX 1}

\section{Scoring Criteria}

Rater:

\section{Content (1-5)}

- The composition contains a clear description of problem and solution

- The details supplied are current, and relevant

- Commentary is insightful

- The writer seems to understand the issue and presents well-developed ideas

\section{Organization (1-5)}

- The introduction contains problem description

- The composition discusses the background of the problem

- The body of the composition is coherent

- Topic sentences are used appropriately

- Paragraphs contain detail and commentary

- Signal phrases and transition words are used correctly and appropriately to transition among ideas

- The conclusion of the composition clearly reemphasizes the topic

\section{Grammar (1-5)}

- Sentences are coherent

- Global and local usage of grammar is fluent and academic, for example:

○ Verb forms are used correctly

- Word forms are used correctly

- Prepositions are used correctly

- Determiners are used correctly

- Spelling is accurate

TOTAL

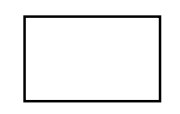


Answer the questions below

\begin{tabular}{|l|l|l|}
\hline $\begin{array}{l}\text { Problem / Solution } \\
\text { The author states a } \\
\text { problem and lists } \\
\text { one } r \text { or }\end{array}$ more \\
solutions \\
problem.
\end{tabular}

1. What is the problem?

2. Why does it become the problem?

3. What are the solutions?

\section{APPENDIX 3}

\section{KUISIONER}

Berikan pendapat saudara dengan melingkari huruf bila saudara

\begin{tabular}{|l|l|l|l|l|}
\hline SS & S & TT & TS & STS \\
\hline sangat setuju & setuju & tidak tahu & tidak setuju & sangat tidak setuju \\
\hline
\end{tabular}

1. Penjelasan dosen tentang menulis ekspositori dapat saya pahami dengan jelas
SS
S
TT
TS
STS

2. Penjelasan dosen tentang proses pembelajaran iterative ini dapat saya pahami dengan jelas
SS
S
TT
TS
STS

3. Saya suka dengan model pembelajaran menulis seperti ini 
$\begin{array}{lllll}\text { SS } & \text { S } & \text { TT } & \text { TS } & \text { STS }\end{array}$

4. Model pembelajaran ini dapat meningkatkan kemampuan menulis saya dalam bahasa inggris

$\begin{array}{lllll}\text { SS } & \text { S } & \text { TT } & \text { TS } & \text { STS }\end{array}$

5. Saya merasa nyaman dalam mengikuti proses pembelajaran ini

$\begin{array}{lllll}\text { SS } & \text { S } & \text { TT } & \text { TS } & \text { STS }\end{array}$

6. Saya merasa senang dapat berbagi hasil karangan saya pada tahap 2 dan 3.

$\begin{array}{lllll}\text { SS } & \text { S } & \text { TT } & \text { TS } & \text { STS }\end{array}$

7. Saya merasa senang dapat membaca hasil karangan teman pada tahap 2 dan 3.

$\begin{array}{lllll}\text { SS } & \text { S } & \text { TT } & \text { TS } & \text { STS }\end{array}$

8. Pada tahap 2 dan 3 saya merasa terbantu dalam menulis dengan membaca karangan teman saya sebelumnya.
SS
S
TT
TS
STS

9. Saya merasa kualitas tulisan saya meningkat dari tahap 1, 2, dan 3 .
SS
$\mathrm{S}$
TT
TS
STS

10. Setelah mengikuti pembelajaran ini,kepercayaan diri saya dalam menulis meningkat.
SS
S
TT
TS
STS

11. Berikan pendapat saudara dalam proses belajar ini dalam satu kata misalnya; asyik, bosan, 